\title{
Effect of intercrops and border crops on the diversity of parasitoids and predators in agroecosystem
}

\author{
U. Amala* and T. M. Shivalingaswamy
}

\begin{abstract}
Diversity of parasitoids and predators in the sole cropped and intercropped, border cropped, and hedgerow cropped fields of guava (sole cropped and intercropped with cowpea), mulberry (sole cropped and border cropped with castor), and sapota (sole cropped and intercropped with clusterbean) were documented in two villages Naukalpalya and P Rampura of Kanakapura district in Karnataka, India, during 2016-2017. The parasitoids and predators were collected using yellow pan traps and sweep nets. The variations in the diversity, species richness, and evenness between two cropping systems are discussed in this paper. Diversity indices were worked out. Predators belonging to the families viz., Coccinellidae, Carabidae, Chrysopidae, Syrphidae, and Pentatomidae were recorded. The adult parasitoids belonging to the families Trichogrammatidae, Braconidae, Encyrtidae, and Ichneumonidae were recorded. Shannon-Weiner index, Margalef's richness index, and evenness index found to be higher in the inter/border/hedgerow cropped fields compared to the sole cropped ecosystems. The abundance of the adult stage of the predators and parasitoids of the inter/border/hedgerow crops was found to be higher. The results of the study confirmed the role of crop diversification as a tool to enhance the functional biodiversity of parasitoids and predators for an efficient biological control program.
\end{abstract}

Keywords: Diversity, Parasitoid, Predator, Intercrop, Border crop, Hedgerow

\section{Background}

Conservation biological control is a way of modification of habitat to support and sustain the population of native parasitoids and predators for successful biological control of crop pests. Hedgerows, grassy banks, field strips, beetle banks, intercrops, border crops, and riparian environments that border fields are examples of habitat that can provide overwintering sites and long-term resources for beneficial arthropods (Bone et al. 2009; Pollard and Holland 2006). Crop diversification will provide alternate non-prey foods such as pollen, nectar, and honeydew to the adult stages of the parasitoids and predators. They may also serve as a shelter to overwinter and protect the parasitoids and predators at times of adverse weather and insecticidal sprays (Landis et al. 2000, Gurr et al. 2003). Native flowering buck wheat Eriogonum spp. were reported to sustain the population of range of beneficial insects (predators, parasitoids, pollinators) and have found a place in the habitat restoration strategies in viticulture (James et al. 2014).

Structural heterogeneity in agricultural habitats is the need of the hour in the recent years of crop intensification. Habitat manipulation strategies are an easiest way to enhance the performance and local abundance of the existing community of parasitoids and predators in terms of fecundity, longevity, search ability, and prey conversion efficiency (Corbett and Rosenheim 1996). There is a need to document the effect of habitat manipulation using cover crops/intercrops along with main crop in sustaining and supporting the diversity of parasitoids and predators of crop pests. The present investigation was undertaken to study the diversity and abundance of parasitoids and predators in the sole cropped and intercropped, border cropped, and hedgerow cropped fields.

* Correspondence: amala.uday@gmail.com

Division of Insect Ecology, ICAR-National Bureau of Agricultural Insect

Resources, H A Farm Post, P B No 2491, Bangalore 560024, India 


\section{Materials and methods Site of study}

The survey was conducted during 2016-2017 on bimonthly basis in guava, sapota, and mulberry fields of Kanakapura district of Karnataka, India. In the Kanakapura district, two villages namely Naukalpalya and P Rampura were selected for the survey. In each village, one-acre field was sampled for both monocropped and intercropped fields.

\section{Collection of parasitoids and predators}

Predators and parasitoids were collected using sweep nets, yellow pan traps, and handpicking in the fields of Kanakapura district. The parasitoids and predators were collected from both the monocultured crops (guava, Psidium guajava L., mulberry, Morus alba L., and sapota, Manilkara zapota L.) and from the fields where they were border cropped or intercropped with crop and non-crop flowering plants. Guava and sapota orchards were found to be intercropped with cowpea and cluster bean, respectively. Hedgerows of hemp and castor were observed around the orchards. Mulberry garden was border cropped with castor around the field. Five sweeps using the sweep nets were performed randomly in the survey area to collect aerial bigger sized flying adult stages of parasitoids and predators. Fifteen yellow pan traps at a distance of $5 \mathrm{~m}$ from each other containing alkaline soap solution were installed in the morning $(8.30 \mathrm{~h})$ and collected in the evening hours $(16.30 \mathrm{~h})$ to document smaller sized parasitoids and predators. The adult stage of the insects that showed signs of parasitization were handpicked and brought to the laboratory. The parasitized insects were observed for emergence of parasitoids. Parasitoids and predators collected during each bimonthly observation from different villages were sorted out into different orders and families. The identity of the parasitoids and predators was confirmed by the taxonomists at ICAR-National Bureau of Agricultural Insect Resources (NBAIR) Bengaluru, India.

\section{Data analysis}

Total number of parasitoids and predators collected under each family was recorded. The biodiversity indices were calculated using the PAST Software. ShannonWeiner diversity index (Shannon and Wiener, 1949) took into account the number of individuals as well as number of taxa indicated by $H=-\operatorname{sum}\left(\left(n_{\mathrm{i}} / n\right) \ln \left(n_{\mathrm{i}} / n\right)\right)$ where $n_{\mathrm{i}}$, is the number of individuals of taxon "i". Evenness index was calculated using the Pielou's (1966) formula $e^{H} / S$ where $H$ indicates the Shannon-Weiner index and $S$ indicates the number of taxa. Margalef's richness index was calculated using the formula, $(S-1) / \ln (n)$, where $S$ represents the number of taxa and $n$ indicates the number of individuals.

\section{Results and discussion}

Nineteen different species of parasitoids and predators were recorded in the intercropped, border cropped, and hedgerow cropped systems (Table 1). The predators recorded in the study included the families Anthocoridae (Cardiastethus sp., Geocoris sp., and Orius sp.), Carabidae (Carabus sp.), Coccinellidae (Brumus suturalis F., Coccinella transversalis Fab, C. septempunctata Linn, Pharascymnus horni Weise, Scymnus coccivora Aiyar), Chrysopidae (Chrysoperla zastrowi sillemi EsbenPetersen, Hemerobia sp., Mallada boniensis Okamoto), Pentatomidae (Eocanthecona furcellata Wolff), and Syrphidae (Ischiodon scutellaris Fab.). The parasitoids recorded in the study included Braconidae (Bracon sp.), Encyrtidae (Anagyrus dactylopii Howard and Coccidoxenoides sp.), Ichnuemonidae (Xanthopimpla sp.), and Trichogrammatidae (Trichogramma japonicum Ashmead). Guava trees were found to be infested with mealybug, Maconellicoccus hirsutus Green and Ferrisia virgata Ckll. The damage and sooty mold growth of cottony cushion scale, Icerya purchasi Maskell, and soft scale, Coccus viridis (Green), was observed on sapota trees. In mulberry, leaf rolling symptom caused by Diaphania pulverulentalis Hampson and tukra disease symptom caused by $M$. hirsutus was observed. The parasitoids and predators documented were the generalist predators and hostspecific parasitoids of the soft-bodied insects infesting guava, sapota, and mulberry.

In guava orchard intercropped with cowpea, the highest number of parasitoids and predators was recorded compared to that in the sole cropped. Mealybug-specific parasitoids viz., A. dactylopii and Coccidoxenoides sp. were recorded in the guava orchard intercropped with cowpea Anagyrus dactylopii and Coccidoxenoides perminutus as efficient native parasitoids of grapevine mealybug, $M$. hirsutus, were reported by Amala et al. (2013). Similarly, sapota intercropped with clusterbean was recorded with the highest number of parasitoids and predators compared to that with the sole cropped. Mulberry crop bordered with castor recorded the highest incidence of parasitoids and predators, particularly the native parasitoids of the lepidopteran insects infesting mulberry. Natural parasitization of mulberry leaf roller belonging to the family Pyralidae by Xanthopimpla sp. and Bracon hebetor was reported by Mittal et al. (2011).

The diversity indices of the parasitoids and predators in the sole cropped and inter/border/hedgerow cropped systems were presented in Table 2. The data clearly showed relatively higher diversity of parasitoids and predators in the intercropped/border cropped and hedgerow cropped fields compared to the monocropped fields. Shannon's index indicates both abundance and evenness of the species occurring in a community. In 
Table 1 Parasitoids and predators recorded in sole and diversified ecosystems at Kanakapura district in Karnataka, India, during 2016-2017

\begin{tabular}{|c|c|c|c|}
\hline Crop & Family & Scientific name & $\begin{array}{l}\text { Number of parasitoids/predators per } \\
\text { plant/tree at bimonthly intervals }(n=6)\end{array}$ \\
\hline \multirow[t]{2}{*}{ Guava (sole crop) } & Chrysopidae & Chrysoperla zastrowi sillemi Esben-Petersen & 0.81 \\
\hline & Coccinellidae & Coccinella septempunctata Fab. & 0.35 \\
\hline \multirow[t]{6}{*}{ Guava + cowpea (intercrop) } & \multirow[t]{2}{*}{ Chrysopidae } & C. z. sillemi & 6.50 \\
\hline & & Mallada boniensis Okamoto & 3.00 \\
\hline & \multirow[t]{2}{*}{ Coccinellidae } & Brumus suturalis $\mathrm{F}$. & 0.95 \\
\hline & & Coccinella transversalis Fab. & 2.10 \\
\hline & \multirow[t]{2}{*}{ Encyrtidae } & Anagyrus dactylopii Howard & 2.30 \\
\hline & & Coccidoxenoides sp. & 1.20 \\
\hline Sapota (sole crop) & Chrysopidae & C. z. sillemi & 2.13 \\
\hline \multirow[t]{8}{*}{ Sapota + clusterbean (intercrop) } & \multirow[t]{2}{*}{ Anthocoridae } & Cardiastethus sp. & 0.76 \\
\hline & & Orius sp. & 1.00 \\
\hline & \multirow[t]{3}{*}{ Coccinellidae } & C. septempunctata Linn. & 4.10 \\
\hline & & Pharascymnus horni Weise & 1.20 \\
\hline & & Scymnus coccivora Aiyar & 2.70 \\
\hline & Chrysopidae & C. z. sillemi Esben-Petersen & 1.31 \\
\hline & Carabidae & Carabus sp. & 1.02 \\
\hline & Syrphidae & Ischiodon scutellaris Fab. & 2.17 \\
\hline Mulberry (sole crop) & Ichneumonidae & Xanthopimpla sp. & 1.23 \\
\hline \multirow[t]{5}{*}{ Mulberry + castor (border crop) } & Braconidae & Bracon sp. & 3.12 \\
\hline & Geocoridae & Eocanthecona furcellata Wolff & 4.21 \\
\hline & Hemerobidae & Geocoris sp. & 1.62 \\
\hline & Pentatomidae & Hemerobia sp. & 0.31 \\
\hline & Trichogrammatidae & Trichogramma japonicum Ashmead & 1.75 \\
\hline
\end{tabular}

the present study, the index was found to be more than 2.0 in the intercropped/border cropped fields compared to sole cropped ecosystems. In our study, intercropped with leguminous cowpea, cluster bean, and groundnut supported higher population of Chrysopid predators. Venzon et al. (2006) reported that the pollen of the leguminous cover crops pigeon pea (Cajanus cajan L.) and hemp (Crotalaria juncea L.) are suitable for the reproductive success of the green lacewing, Chrysoperla externa. Ensuring the reproductive success of parasitoids and predators with a direct positive effect on the numerical response of predators is a vital factor for a successful conservation biological control of crop pests.

Intercrops and border crops during flowering provide ample nectar, pollen, and shelter for the resident parasitoids and predators. They also protect them by providing shelter to the native parasitoids and predators during insecticidal sprays in the main crop. This provides an added advantage of favorable microclimate for the population build up of parasitoids and predators. Alignier et al. (2014) reported that hedgerows of non-crop plants supported diverse population of parasitoids and predators with higher

Table 2 Diversity indices of parasitoids and predators in sole cropped and intercropped, border cropped, and hedgerow cropped fields at Kanakapura district in Karnataka, India, during 2016-2017

\begin{tabular}{lllll}
\hline Crop & Cropping system & Shannon-Weiner diversity index & Margalef richness index & Evenness index \\
\hline Guava* & Sole crop & 1.73 & 1.92 & 0.19 \\
& Guava + cowpea (intercrop) & 3.09 & 2.40 & 0.89 \\
Mulberry & Sole crop & 1.02 & 1.86 & 0.42 \\
& Mulberry + castor (border crop) & 2.83 & 2.23 & 0.95 \\
Sapota* & Sole crop & 1.75 & 1.91 & 0.89 \\
& Sapota + clusterbean (intercrop) & 2.19 & 2.42 & 0.94 \\
\hline
\end{tabular}

*Hedgerow cropping of castor and hemp was observed 
rates of parasitism of aphids in wheat. Timing of sowing the inter-crops or border crops is a crucial factor in sustaining the synchrony between the parasitoids and predators and insect pests in agro-ecosystems.

Evenness index is a measure of distribution of a species in an ecosystem. An evenness value of 1 indicates the uniformity in the distribution of species. In our results, the intercropped/border cropped fields recorded evenness indicating uniform distribution of species compared to the sole cropped ecosystems. The results were in line with the observations made of Anbalagan et al. (2016) who reported maximum diversity, richness, and evenness of natural enemy complex in the vegetables intercropped with castor, roselle (Hibiscus sabdariffa L.), cowpea, and agathi (Sesbania grandiflora L.) compared to those in the sole cropped. Margalef's richness index is a measure of species richness with a positive correlation towards diversity in an ecosystem. Under intercropped systems, the richness index was found to be more compared to the sole cropped areas. Seminatural habitats consisting of crop and noncrop plants within the farm areas help in colonization of resident parasitoids and predators thereby resulting in efficient natural reduction of crop pests (Sarthou et al. 2005; Rand et al. 2006).

\section{Conclusions}

Holistically, the natural enemy fauna abundance and diversity were found to be greater in the intercropped, border cropped, and hedgerow cropped fields compared to the sole cropped fields. Provisioning the parasitoids and predators with flowering intercrops/border crops will help in sustaining their population in the agricultural habitats to enhance biological control of insect pests.

Habitat manipulation strategies using hedgerows and strips of non-crop plants should be integrated with the farm landscape in a spatial and temporal way to benefit parasitoids and predators for natural biological control of insect pests.

\section{Authors' contributions}

UA carried out the field visits and sampled the parasitoids and predators and performed statistical analysis. TMS conceived of the study and participated in design and coordination. Both authors read and approved the final manuscript.

\section{Competing interests}

The authors declare that they have no competing interests.

\section{Publisher's Note}

Springer Nature remains neutral with regard to jurisdictional claims in published maps and institutional affiliations.

Received: 19 June 2017 Accepted: 6 December 2017

Published online: 08 February 2018

\section{References}

Alignier A, Raymond L, Deconchat M, Menozzi P, Monteil C, Sarthou JP, Vialatte A, Ouin A (2014) The effect of semi-natural habitats on aphids and their natural enemies across spatial and temporal scales. Biol Cntrl 77:76-82
Amala U, Yadav DS, Bhosale AM (2013) Studies on parasitoid complex of mealybug infesting grapes in Maharashtra. J Appl Horti 15:117-119

Anbalagan V, Paulraja MG, Ignacimuthua S, Baskar K, Gunasekaran J (2016) Natural enemies (Arthropoda-Insecta) biodiversity in vegetable crops in Northeastern Tamil Nadu, India. Int Let Nat Sci 53:28-33

Bone NJL, Thomson J, Ridland PM, Cole P, Hoffmann AA (2009) Cover crops in Victorian apple orchards: effects on production, natural enemies and pests across a season. Crop Protec 28:675-683

Corbett A, Rosenheim JA (1996) Impact of a natural enemy overwintering refuge and its interaction with the surrounding landscape. Ecol Entomol 21:155-164

Gurr GM, Wratten SD, Luna JM (2003) Multi-function agricultural biodiversity: pest management and other benefits. Basic Appl Ecol 4:107-116

James DG, Seymour L, Lauby G, Buckley K (2014) Beneficial insects attracted to native flowering buckwheats (Eriogonum michx) in Central Washington. Environ Entomol 43(4):942-948

Landis DA, Wratten SD, Gurr GM (2000) Habitat management to conserve natural enemies of arthropod pests in agriculture. Annu Rev Entomol 45:175-201

Mittal V, Illahi I, Dhar A, Khan MA (2011) Natural enemies of mulberry pyralid, Glyphodes pyloalis Walker (Lepidoptera: Pyralidae), in temperate climate of Kashmir. J Biol Cntrl 25(1):55-57

Pielou EC (1966) The measurement of diversity in different types of biological collections. J Theoretical Biol 13:131-144

Pollard KA, Holland JM (2006) Arthropods within the woody element of hedge rows and their distribution pattern. Agric For Entomol 8:203-211

Rand TA, Tylianakis JM, Tscharntke T (2006) Spillover edge effects: the dispersal of agriculturally subsidized insect natural enemies into adjacent natural habitats. Ecol Lett 9:603-614

Sarthou JP, Ouin A, Arrignon F, Barreau G, Bouyjou B (2005) Landscape parameters explain the distribution and abundance of Episyrphus balteatus (Diptera: Syrphidae). Eur J Entomol 102:539-545

Shannon CE, Wiener W (1949) The mathematical theory of communication. University of Illinois Press, Urbana

Venzon M, Rosado MC, Euzebio DE, Souza B, Schoereder JH (2006) Suitability of leguminous cover crop pollens as food source for the green lacewing Chrysoperla externa (Hagen) (Neuroptera: Chrysopidae). Neotrop Entomol 35(3):371-376

\section{Submit your manuscript to a SpringerOpen ${ }^{\mathcal{O}}$ journal and benefit from:}

- Convenient online submission

Rigorous peer review

- Open access: articles freely available online

- High visibility within the field

- Retaining the copyright to your article

Submit your next manuscript at springeropen.com 